\title{
TAWARAN DALAM PENEGAKAN HUKUM KEBAKARAN HUTAN DARI HUKUM PROGRESIF MENUJU PARADIGMA PROFETIK
}

\author{
Elviandri \\ elviandri@umri.ac.id
}

Fakultas Hukum Univ. Muhammadiyah Riau

\section{ABSTRACT}

Hampir setiap tahun kebakaran lahan dan hutan terjadi di beberapa wilayah Indonesia. Selama penegakan hukum kebakaran hutan masih menggunakan pendekatan postivistik, maka keadilan yang didambakan akan semakin absurt dirasakan oleh masyarakat. Pendekatan paradigma profetik menurut penulis dapat memecahkan kebuntuan itu. Paradigma profetik dalam penegakan hukum dimulai dengan pembinaan penegak hukum melalui kecerdasan spiritual yang ditawarkan oleh Danah Zohar dan Ian Marshall. Pendekatan yang mereka gunakan adalah dengan mengenalkan berpikir spiritual (spiritual tinking). Melalui kecerdasan spiritual (spiritual quition), akan diperoleh kecerdasan yang paling sempurna (ultime intelegent) sehingga dapat menerabas garis-garis formalisme (existing rule) menuju trasedental yang mendekati kebenaran yang hakiki (the ultimate truth). Pembinaan hakim dengan pendekatan SQ sesuai dengan amanat tugas seorang hakim yang menjatuhkan keputusan berdasarkan "Demi Keadilan Berdasarkan Ketuhanan Yang Maha Esa". Tugas yang dijalankan seorang hakim adalah tugas spiritual dengan mengatasnamakan Tuhan dan Keadilan.

Kata Kunci : Penegakan Hukum, Paradigma Profetik, Hukum Progresif

\section{ABSTRAK}

Hampir setiap tahun kebakaran lahan dan hutan terjadi di beberapa wilayah Indonesia. Selama penegakan hukum kebakaran hutan masih menggunakan pendekatan postivistik, maka keadilan yang didambakan akan semakin absurt dirasakan oleh masyarakat. Pendekatan paradigma profetik menurut penulis dapat memecahkan kebuntuan itu. Paradigma profetik dalam penegakan hukum dimulai dengan pembinaan penegak hukum melalui kecerdasan spiritual yang ditawarkan oleh Danah Zohar dan Ian Marshall. Pendekatan yang mereka gunakan adalah dengan mengenalkan berpikir spiritual (spiritual tinking). Melalui kecerdasan spiritual (spiritual quition), akan diperoleh kecerdasan yang paling sempurna (ultime intelegent) sehingga dapat menerabas garis-garis formalisme (existing rule) menuju trasedental yang mendekati kebenaran yang hakiki (the ultimate truth). Pembinaan hakim dengan pendekatan SQ sesuai dengan amanat tugas seorang hakim yang menjatuhkan keputusan berdasarkan "Demi Keadilan Berdasarkan Ketuhanan Yang Maha Esa”. Tugas yang dijalankan seorang hakim adalah tugas spiritual dengan mengatasnamakan Tuhan dan Keadilan.

Kata Kunci : Penegakan Hukum, Paradigma Profetik, Hukum Progresif 


\section{PENDAHULUAN}

Kebakaran lahan dan hutan yang terjadi akhir-akhir ini di beberapa wilayah Indonesia telah menjadi perhatian serius baik nasional maupun internasional. Dampak kebakaran tidak hanya dirasakan oleh masyarakat Indonesia tapi juga beberapa Negara tetangga seperti Singapura dan Malaysia. Berdasarkan pantauan satelit NASA yang ada 561 titik api yang tersebar di 18 provinsi seluruh Indonesia. Luas kerusakan hutan akibat kebakaran, perambahan, pembalakan liar sepanjang 2014-2015 mencapai 10,5 juta Ha. Selain itu, lebih dari 60.000 orang menderita infeksi saluran pernafasan atas (ISPA).

Bencana kebakaran ini berpotensi mengundang bencana susulan yang lebih besar, berupa bencana ekologi serta bencana sosial. Kerusakan lingkungan, kepunahan keanekaragaman hayati, banjir, longsor, kekeringan, hingga meledaknya hama akibat kacaunya sistem rantai makanan di alam. Belum lagi peningkatan jumlah penduduk miskin, kerawanan pangan, kerentanan terhadap kesehatan dan keselamatan manusia akibat semakin berkurangnya akses masyarakat terhadap sumberdaya lahan dan hutan semakin mengancam kehidupan masyarakat. Bahkan diskriminasi dan pelanggaran hak asasi manusia.

Bencana kebakaran yang terjadi saat ini merupakan "puncak gunung es" dari permasalahan tata kelola lahan dan hutan di Indonesia. Hampir setiap tahun kebakaran lahan dan hutan terjadi di beberapa wilayah Indonesia. Intensitas dan luas cakupan kebakaran tidak ada perubahan secara signifikan.

Hasil studi Forest Watch Indonesia (FWI) pada tahun 2003 menunjukkan bahwa pembukaan lahan dengan cara membakar hutan tidak terbatas pada Kalimantan dan Sumatera saja. Kebakaran dilaporkan terjadi di 23 dari 27 provinsi di Indonesia pada tahun 1997-1998. Sejumlah besar kebakaran hutan yang terjadi di kedua pulau utama tersebut disebabkan oleh perusahaan perkebunan dan berbagai proyek pemerintah, hal ini berakibat terhadap lenyapnya puluhan ribu hektare hutan pada satu kesempatan saja.

Bencana asap ini bukan yang pertama kali, mestinya pemerintah bisa menjadikan pembelajaran dari bencana sebelumnya. Hal ini menunjukan lemahnya kapasitas pemerintah dalam mengelola sumber daya alam. Selain itu, tidak adanya review dan audit 
perizinan terutama pada lahan gambut yang selama ini terjadi proses pengeringan oleh konsesi perusahan menjadi salah satu faktor utama penyebab bencana ini terjadi. Kejadian ini akan terus berulang ditahun-tahun mendatang apabila penegakan hukum terhadap pelaku pembakaran masih lemah dan tidak menimbulkan efek jera. Pemerintah berkewajiban mendapatkan layanan lingkungan yang sehat.

Beberapa putusan pengadilan menunjukkan bahwa hukum yang diputuskan tidak berkeadilan.

Diantaranya, Pertama, putusan menjamin hak warga negaranya dalam

perdata ke PT. Nasional Sago Prima yang pemegang sahamnya adalah PT. Sampoerna Agro TBK lagi-lagi hakim tidak berpihak kepada rasa keadilan bagi rakyat yang terkena dampak kebakaran hutan. Dari tuntutan perdata KLHK sebesar Rp. 1,079 triliun Majelis Hakim yang dipimpin Sarah Loui menghukum PT. Nasional Sago Prima dengan denda hanya Rp. 2 Miliar. $^{2}$

Kendala dalam penegakan hukum diantaranya adalah faktor politik, peran pemerintah, bekerjanya hukum, Ipteks dan sosial budaya. Menurut Stephen Trudgill, faktor yang Pengadilan Negeri Palembang 30 dan mengatasi masalah-masalah Desember 2015 yang menolak gugatan lingkungan adalah faktor politik, perdata Kementerian Lingkungan disamping faktor ekonomi, hukum, Hiidup dan Kehutanan (KLHK) ke PT. sosial-budaya, teknologi dan Bumi Mekar Hijau (BMH), anak pengetahuan. perusahaan Asia Pulp and Paper (APP) Kekuatan politik mempunyai hakim tidak berpihak kepada rakyat pengaruh besar terhadap bekerjanya yang terkena dampak kebakaran hukum. Berbagai kasus penegakan hutan. ${ }^{1}$

Kedua, Kementerian Lingkungan hukum, kebakaran hutan di Palembang dan Riau sangat dipengaruhi Hidup dan Kehutanan (KLHK) kepentingan politik. Disamping itu meskipun kalah pada Pengadilan penyebab kegagalan penegakan hukum Negeri Palembang tidak menyurutkan lingkungan di pengadilan karena hakim keinginannya untuk menggugat secara

\footnotetext{
${ }^{1}$ Tempo, Hukum Pembakaran Hutan, 31 Januari 2016. hlm. 65-67
} tidak melihat pada pertimbangan hukum lain, asas-asas hukum yang

${ }^{2}$ Ibid. 
hidup atau asas hukum mempunyai kedudukan lebih tinggi, seperti prinsip pencegahan dini, prinsip kehati-hatian (precautionary), pertanggungjawaban ketat (strict liabilty) dan sustainable development. Prinsip tersebut amat dibutuhkan untuk menjawab persoalan hukum dalam perkara yang tidak terakomodasi dalam peraturan-perundang-undangan. Hakim juga tidak melihat fakta hukum yang terungkap di persidangan sehingga putusan hakim dalam menyelesaikan sengketa lingkungan dianggap tidak mencerminkan rasa keadilan. ${ }^{3}$

Selama penegakan hukum kebakaran hutan masih menggunakan pendekatan postivistik semata-mata maka, keadilan yang diadambakan akan semakin absurt dirasakan oleh masyarakat. Maka pendekatan paradigma profetik dalam penegakan hukum kebakaran hutan menurut penulis dapat memecahkan kebuntuan itu. Pada pendekatan paradigma profetik dalam penegakan hukum kebakaran hutan menuntut keberanian aparat hukum menafsirkan pasal untuk memperadabkan bangsa. Apabila proses tersebut benar, idealitas yang

\footnotetext{
3 Absori, Penegakan Hukum Terhadap Kejahatan Korporasi di Bidang Lingkungan Hidup. Slide Pemakalah, tidak dipublikasikan.
}

dibangun dalam penegakan hukum di Indonesia sejajar dengan upaya bangsa mencapai tujuan bersama. Idealitas itu akan menjauhkan dari praktek ketimpangan hukum yang tak terkendali seperti sekarang ini. Manusia menciptakan hukum bukan hanya untuk kepastian, tetapi juga untuk kebahagiaan. Kajian ini memfokuskan diri pada proses ingsutan hukum progresif menuju paradigma profetik dalam penegakan hukum kebakaran hutan.

\section{METODE PENELITIAN}

Tulisan ini bersifat deskriptif ${ }^{4}$ dengan pedekatan studi kepustakaan (Library Reasearch), dengan cara mengiventarisir berbagai bahan pustaka utama dan pendukung yang berkaitan dengan fokus permasalahan untuk memperoleh gambaran yang bersifat umum dan relatif menyeluruh, tentang ingsutan hukum progresif menuju paradigma profetik dalam

\footnotetext{
${ }^{4}$ Metode penelitian deskriptif analitis adalah metode yang mengkaji masalah-masalah dalam masyarakat dan tata cara yang berlaku dalam masyarakat serta situasi-situasi tertentu, termasuk tentang hubunganhubungan, kegiatan-kegiatan, sikap-sikap, pandangan-pandangan, serta proses-proses yang sedang berlangsung dan pengaruhpengaruh dari suatu fenomena. Penelitian deskriptif bertujuan untuk membuat deskripsi atau gambaran secara sistematis, faktual, dan akurat mengenai fakta, sifat, serta hubungan
} 
penegakan hukum kebakaran hutan. hukum, dan kelembagaan, masalah Dengan dilakukannya cara ini, selain kebakaran di Indonesia tidak akan diperoleh berbagai informasi yang pernah selesai secara permanen. diperlukan, penulis juga mendapatkan Kebakaran sebagian besar terjadi di pengetahuan tingkat permukaan, lahan-lahan konsesi perkebunan dan tentang berbagai bagian dari fokus hutan tanaman industri (HTI). Ini permasalahan tertentu. merupakan bentuk kegagalan

\section{HASIL PENELITIAN}

\section{A. Penegakan Hukum Kebakaran Hutan: Keadilan yang Absurd}

Pemerintah belum mempunyai resolusi kebijakan jangka panjang untuk menangani kebakaran yang hampir setiap tahun terjadi. Penanggulangan kebakaran yang ada masih berkutat seputar teknis pencegahan dan pemadaman kebakaran. Kasus kebakaran hutan di Indonesia merupakan masalah struktural pengelolaan sumber daya alam, yang hanya dapat diselesaikan dengan pendekatan skema kebijakan, hukum, dan kelembagaan secara progresif. Anggaran mencapai Rp 385 milliar yang disiapkan pemerintah tahun ini hanya dapat dibenarkan sebatas untuk menyelamatkan dan meminimalisir dampak lingkungan yang akan terjadi. Akan tetapi, tanpa ada intervensi di level kebijakan,

antar-fenomena yang diteliti (Nazir, 1999:6364) pengelolaan yang dilakukan oleh para pemegang konsesi yang tidak melibatkan masyarakat sekitar kawasan sebagai mitra kerja dengan posisi sejajar.

Dalam konteks kebakaran hutan ini menurut Elviandri terdapat beberapa hal yang menjadi landasan pembenar bagi multinasional/MultiNational Corporation (MNC) untuk melanjutkan kegiatan ini dalam perspektif hukum dan ekonomi.

Pertama, motivasi ekonomi memang menjadi faktor dominan pada tataran yang lebih massif dengan modal serendah-rendahnya, mendapatkan untung setinggi-tingginya dan menjadi trigger dalam praktek adanya pembakaran lahan yang dilakukan oleh beberapa perusahaan besar.

Kedua, kecenderungan dari lemahnya upaya penegakan hukum yang terjadi pada saat ini membuat multinasional/Multi-National

Corporation (MNC) menganggap 
kemungkinan mereka untuk dikenakan sanksi lebih sedikit. Ini membuktikan bahwa hukum belum menjadi panglima yang dapat diandalkan untuk memberikan efek jera atas pembakar lahan penyebab kabut asap.

Ketiga, diskursus hukum lingkungan di Indonesia saat ini masih menempatkan korporasi sebagai subyek hukum hanya dalam tataran normatif belaka semakin memperkecil peluang untuk menghukum dari para pelaku kejahatan lingkungan.

Keempat, kelalaian, dan minimnya kontrol baik dari pemerintah pusat maupun daerah, menambah terbukanya peluang bagi perusahaan multinasional/Multi-National

Corporation (MNC) yang bercokol dan bernaung dibawah bendera kapitalisme dan mengabaikan aspek lingkungan.

Kelima, ketidak berdayaan pemerintah dalam menjatuhkan sanksi tegas seperti pencabutan izin operasional atau pembekuan aktivitas perusahaan. Hal hal ini disebabkan adanya tekanan dari multinasional/Multi-National

Corporation

(MNC) yang

mengatasnamakan masyarakat. Karena dengan diberikan izin operasional maka dapat menyerap tenaga kerja dan mengurangi pengangguran.

\section{Perusahaan}

multinasional/Multi-National

Corporation (MNC) dengan bendara kapitalisme telah menjadi ancaman terhadap Indonesia terutama dalam eksploitasi hutan sehingga menyebabkan kerusakan lingkungan hidup yang sistemik, mulai dari pembakaran hutan, alih fungsi lahan hingga membabat habis hutan lindung dan kawasan konservasi.

Hal tersebut tanpa

memperhatikan dan mempertimbangkan dampaknya bagi jutaan masyarakat. Kabut asap yang sedang kita alami ini merupakan puncak dari fenomena gunung es atas faktor keserakahan kapitalisme dalam mengekploitasi SDA sehingga mengesampingkan kearifan terhadap lingkungan. ${ }^{5}$

Roberto M. Unger ${ }^{6}$ mengatakan bahwa pemahaman hukum tidak bisa bebas dari konteksnya. Hukum bekerja tidak di ruang hampa tetapi bekerjadalam realitas yang tidak netral dari pengaruh lain, dan nilai yang ada di belakangnya adalah subjektif. Hukum bukanlah sesuatu yang terjadi

5 Elviandri, Tanda Ketidak Berdayaan Pemerintah, Artikel Harian Vokal - Riau, 14 September 2015

${ }^{6}$ Roberto M Unger, 1999, The Critical Legal Studies Movement (1983), diterjemahkan Ifdhal Kasim, Jakarta: Elsam, hal. 22. 
secara alamiah, melainkan dikontruksi secara sosial. Karena itu, penggunakan hukum yang hanya bersifat formal akan gagal untuk mengatasi problem kemasyarakatan. Dia mencoba mengetengahkan visinya mengenai tatanan masyarakat dan tatanan hukum masa mendatang melalui gerakan aktivitas transformatif yang dilakukan atas dasar hak-hak individu yang dilindungi hukum dan menyadarkan birokrasi kekuasan untuk bekerja dengan penuh tanggung jawab.

Selama ini lembaga pengadilan sebagai lembaga negara penegak keadilan dalam melakukan penegakan hukum lingkungan dinilai tidak memberi rasa keadilan masyarakat, dan keadilan lingkungan. Berbagai kasus penyelesaian sengketa pencemaran lingkungan yang diajukan ke pengadilan keputusannya amat mengecewakan masyarakat, dan jauh dari rasa keadilan. Lembaga pengadilan dalam menyelesaikan sengketa lingkungan selama ini masih berorientasi pada hukum formal. Analasis studi menunjukan bahwa dalam menyelesaikan sengketa lingkungan hakim masih belum mampu keluar dari pendekatan text books yang memahami hukum sebatas aturan yang bersifat hitam putih, diterapkan laksana buku telepon. Hal ini dapat dilihat dari ketidakberanian hakim untuk keluar dari rumusan ketentuan hukum perdata yang bersandar pada Pasal 1365 KUHPerdata ataupun Pasal 34 UU No. 23 Tahun 1997 tentang Pengelolaan Lingkungan Hidup dalam menangani gugatan masyarakat.

Hakim sama sekali tidak melihat pada petimbangan hukum lain yang terdapat dalam asas-asas hukum yang hidup di masyarakat atau asas hukum mempunyai kedudukan lebih tinggi, seperti prinsip pencegahan secara dini, prinsip kehati-hatian (precautionary), prinsip pembelaan melalui "due diligence" dan prinsip pertangungjawaban ketat (strict liability) padahal prinsip-prinsip tersebut amat dibutuhkan untuk menjawab persoalan hukum dalam perkara yang tidak terakomodasi dalam perundang-undangan. Di samping itu, hakim juga tidak melihat fakta hukum yang terungkap di persidangan sehingga keputusan hakim dalam menyelesaikan sengketa lingkungan dianggap tidak mencerminkan rasa keadilan. Kegagalan lembaga pengadilan dalam menyelesaikan sengketa lingkungan karena aparat penegak hukum (hakim) dalam memahami dan menerapkan hukum 
baru sebatas menggunakan logika peraturan dan prosedur yang bersifat legal formal. ${ }^{7}$

Penegakan hukum lingkungan yang dilakukan lembaga formal, seperti pengadilan dan pemerintah selama ini belum bergesar dari pendekaatan positivis formal dan prosedural. Aparat penegak hukum dalam merespon dan menyelesaikan berbagai persoalan lingkungan menunjukan sikap yang formalis, deterministik, dan memberi peluang terjadinya perilaku eksploitatif di kalangan pelaku usaha (investor). Instrumen hukum yang dipakai hanya berorientasi prosedur dan tidak dapat diandalkan sebagai pilar utama untuk mengatasi problem lingkungan, sementara pencemaran lingkungan dalam proses waktu semakin sulit untuk dapat dikendalikan. ${ }^{8}$

Karena itu, pendekatan seperti itu kiranya perlu segera diakhiri, diganti dengan semangat pendekatan hukum progresif yang dimulai dari kesadaran yang tumbuh dari semua kalangan yang mempunyai kepedulian terhadap lingkungan untuk memahami bahwa persoalan lingkungan sudah mencapai tarap yang

mengkhawatirkan. Karena itu, perlu ada terapi kejut (shock therapy) yang segera digulirkan dalam berbagai upaya dan langkah dalam rangka memberikan dorongan yang lebih kuat lagi. Untuk mengatasinya perlu dilakukan gerakan penyadaran secara progresif dengan melibatkan pertisipasi masyarakat, aparatpenegak hukum, dan pemerintah akan tugas dan tangung jawabnya dalam menyelesaikan dan memecahkan masalah-masalah lingkungan.

Menurut Hamrat Hamid dalam kasus persidangan sengketa lingkungan, mestinya perlu dipertimbangkan, pertama, motif atau alasan terdakwa. Kedua, kesungguhan terdakwa dalam melakukan pencegahan tercemar atau rusaknya lingkungan hidup. Ketiga, besar kecilnya bencana atau bahaya terhadap jiwa atau kesehatan manusia. Keempat, besar-kecilnya perhatian, keperdulian, dan bantuan perusahaan tersebut pada masyarakat sekitar, terutama masyarakat ekonomi lemah. Kelima, ada tidaknya peringatan atau teguran dari aparat atau instansi pemerintah yang berwenang. ${ }^{9}$

\footnotetext{
${ }^{7}$ Absori, Penegakan Hukum Lingkungan D Era Reformasi, Jurnal Ilmu Hukum, Vol 8 No.2, 2005.
}

\footnotetext{
${ }^{9}$ Hamid, Hamrat dan Pramudyanto, Bambang. 2007. Pengawasan Industri Dalam Pengendalian Pencemaran Lingkungan, Edisi I. Jakarta : Granit.
} 
Dalam konteks ini untuk dapat menjalankan hukum lingkungan di tengah masyarakat yang penuh dengan kompleksitas, dibutuhkan aparat penegak hukum, yakni polisi, jaksa, dan hakim yang mempunyai visi, komitmen yang kuat, dan pengetahuan yang memadai di bidang lingkungan. Karena itu, sudah saatnya perlu dilakukan rekrutmen dan pembinaan aparat penegak secara khusus, yang nantinya diharapkan dapat menjalankan tugas khusus dalam menangani sengketa ataupun pengaduan masyarakat masalah lingkungan, berupa perusakan atau pencemaran lingkungan. Hakim yang diangkat atau ditunjuk dapat saja direkrut dari kalangan akademisi atau pakar hukum lingkungan, praktisi yang mengetahui seluk-beluk masalah lingkungan, ataupun kalangan aktivis yang selama ini gigih memperjuangkan lingkungan. ${ }^{10}$

\section{B. Pilihan Hukum: Dari Hukum Progresif Menuju Paradigma Profetik}

Ilmu modern yang positivistik selama ini berada dalam koridor hegemoni modernisme-positivisme

${ }^{10}$ Absori, Penegakan Hukum Lingkungan dan Antisispasi Dalam Era Perdagangan Bebas, (paradigma Newtonian). Paradigma ilmu modern yang positivistik dengan doktin empirisme, objektivisme, dan rasionalisme mulai digugat kaum posmodernisme yang pospositivistik dengan mengedepankan makna dibalik itu yang menjadi lebih terbuka dan utuh. Boleh dikatakan ilmu dari waktu ke waktu mengalami perubahan yang biasanya dimulai dari perubahan dalam paradigma yang digunakan.

Salah satu peristiwa besar dalam dunia ilmu pengetahuan adalah berakhirnya era Newton melalui suatu revolusi dan untuk waktu yang lama diterima sebagai keunggulan ilmu pengetahuaan yang mampu mengakhiri keterbatasannya untuk menjelaskan dan mempetakan alam. Sejak fisika dan paradigma Newton yang baru maka seluruh alam dianggap telah dapat dilihat dalam suatu susunan yang tertib. 11

Tetapi era Newton bukan akhir segalanya, alam masih menyimpan kompleksitas yang tidak dapat dijelaskan atau dijangkau oleh teori Newton. Kini era Newton diganti

Muhammadiyah University Press, Surakarta, 2001.

11 Absori, Epistimologi Ilmu Hukum Transendental dan Implementasinya dalam Pengembangan Program Doktor Ilmu Hukum, Disampaikan pada Seminar Nasional dengan Tema "Pengembangan Epistimologi 
dengan Relativitas Einstein yang lebih mampu mengamati fenomena alam yang kompleks.Teori baru tentang alam, seperti teori kuantum modern dan teori chaos telah mengubah pandangan manusia modern yang dulunya beranggapan bahwa sesuatu (alam) bersifat jelas dan pasti kemudian berubah mengalami dekontruksi tidak hanya dalam tataran fisik, realitas tetapi juga simbolik.

Pengembangan ilmupun mengalami perubahan paradigmatik tidak hanya dalam bidang ilmu eksak (fisik alam) tetapi juga ilmu sosial (perilaku manusia). Posmodernisme mulai mengangkat hal-hal yang sifatnya irasional (emosi, perasaan, intuisi, pengalaman personal, spekulasi), moral, dan spiritual sebagai bagian integral dalam memahami kajian/persoalan keilmuan. Pemikiran hukum yang dianggap tidak puas (kritis bahkan memberontak) terhadap terhadap paradigama hukum modern yang liberal dan mapan yang dikategorikan sebagai pemikiran posmodernisme.

Hal tersebut disebabkan adanya asumsi mekanistik-deterministik yang berpadu dengan asumsi reduksionis-

Ilmu Hukum", 11 April 2015 di Universitas Muhammadiyah Surakarta. Hal.2 atomistik melahirkan pandangan bahwa alam semesta adalah sebuah mesin raksasa yang telah mati dan bergerak statis. Ia kemudian direduksir untuk dibersihkan dari nilai nilai estetis dan etis, dimiskinkan dari nilai simbolik dan kualitatif. Alam menjadi entitas yang bebas nilai dan tunduk kepada hukum hukum logis.

Implementasi Teori Hukum Murni menjadikan hukum lepas dari aras moral dan nilai-nilai agama. Misal, putusan vonis penjara terhadap nenek tua pencuri buah kakao adalah benar sesuai logika hukum karena tindakanya memenuhi unsur-unsur pidana, meskipun nurani kita berontak untuk mengatakan tidak. Fenomena ini menunjukan hukum tidak memberi ruang kepada moralitas maupun nilai keilahian, yang dianggapnya sebagai unsur non-yuridis.

Positivisme menolak pertanggungjawaban pengetahuan yang berasal dari luar batas empiris dan hukum-hukum ilmu pengetahuan. Ilmu pengetahuan haruslah dianggap sebagai objek yang harus dilepaskan dari segala macam prakonsepsi metafisis dan subjektif sifatnya. Pandangan ini dimaksudkan sebagai kritik atas monopoli pengetahuan yang bersifat dogmatis, liturgis, dan misitis. 
Filsafat modern yang maka mau tidak mau kejaksaan harus rasionalistik dengan madzhab filsafat direkonstruksi terhadap tiga komponen hukum positivistik mewarnai secara sekaligus yaitu kelembagaan paradigma penegakan hukum di kultur dan substansi hukum. ${ }^{12}$

Indonesia. Paradigma postivistik Dalam dimensi tradisi tersebut muncul dengan karakter: paradigma positivistik itulah terbaca birokratis, sentralistik, menganut prilaku para penegak hukum di pertanggungjawaban hierarkis dan Indonesia yang tidak mampu bergerak berlaku sistem komando. emansipatoris dan progresif, tetapi Konvensionalitas birokrasi selain sekedar menjadi alat yang menjadi media bersembunyi instrumentalis, corong undang-undang penyimpangan juga menjadikan jaksa dan pengetok palu dari teks-teks pasal tidak memiliki ruang untuk yang dirumuskan dalam arena ruang menuangkan kreativitas, inovasi dalam kekuasaan. Keadilan kemudian sekedar menembus keterbatasan hukum positif diukur dari bunyi-bunyi pasal yang serta menjadikan jaksa tidak kaku dan dogmatik. Sedangkan independen. Penegakan hukum yang terobosan-terobosan penemuan hukum dilakukan oleh kejaksaan hanya yang responsif dan progresif mati suri. berorientasi pada terwujudnya Hukum yang hidup di masyarakat procedural justice yang cenderung dimarjinalisasi bahkan terhapuskan. memarginalkan substantial justice. Lebih buruk lagi, ditengah paradigma Untuk itu dengan bertumpu pada sakuralisme kesucian teks-teks pasal pendekatan hukum progresif, mestinya yang logis tersebut, aparat penegak kita harus melakukan rekonstruksi hukum di Indonesia telah biasa penegakan hukum berdasarkan spirit melangsungkan praktek jual beli pasal pembebasan terhadap: pertama, tipe, untuk mempertebal kantong-kantong cara berpikir, asas dan teori yang saku mereka.

selama ini dipakai birokrasi penegakan hukum; dan kedua, pembebasan terhadap kultur penegakan hukum yang selama ini berkuasa dan dirasa menghambat penanganan perkara. Untuk menjamin keberlangsungannya,

\footnotetext{
${ }^{12}$ Yudi Kristiana, 2007, Rekonstruksi Birokrasi Kejaksaan dengan Pendekatan Hukum Progresif dengan subjudul Studi tentang Penyelidikan, Penyidikan, dan Penuntutan Tindak Pidana, Disertasi Program Doktor Ilmu Hukum Program Pascasarjana Universitas Diponegoro Semarang, tidak dipublikasikan.
} 
Krisis penegakan hukum di Indonesia yang statis, merupakan salah satu dampak dari paradigma penegakan hukum di Indonesia yang masih bersandar terhadap tipe tradisi hukum kontinental (rule of law). Tradisi hukum kontinental terklasifikasi sebagai tipe pembangunan hukum yang ortodoks karena mencirikan peranan yang sangat dominan dari lembaga-lembaga negara (pemerintah dan parlemen) dalam menentukan arah hukum dalam suatu masyarakat. Hukum bersifat positivisinstrumentalis dan menjadi alat yang ampuh bagi pelaksanaan ideologi dan program negara. ${ }^{13}$ Berbeda dengan paradigma responsif yang ada pada hukum adat. Dimana ciri utamanya ialah adanya peranan besar dari lembaga-lembaga peradilan dan partisipasi yang luas bagi kelompokkelompok sosial atau individu-individu di masyarakat dalam menentukan arah pembangunan hukum.

Berbagai pemikiran hukum di atas memperlihatkan bahwa terdapat problematika paradigmatik dan krisis kesadaran etis dalam penegakan hukum di Indonesia. Sehingga yang muncul adalah penegakan hukum yang

${ }^{13}$ Abdul Hakim G. Nusantara, Politik Hukum Indonesia, Yayasan Lembaga Bantuan Hukum Indonesia, Jakarta, 1988, hlm 27 stagnan, sentralistik, koruptif dan sangat jauh dari nilai-nilai yang humanis.

Oleh Karenanya, diperlukan interaksi antara hukum atau ilmu hukum dengan nilai-nilai spriritual, yang meiputi: etika, moral dan agama. Dengan mendasarkan kajiannya dari filsafat Emergency dari Phillip Clayton tentang dialog nilai, serta teori the unity of knowladge (yang dikonsepkan dalam istilah "Consilience), dari Edward O Wilson. Upaya untuk mendiskusikan kembali secara intens dan mendalam persoalan hukum, agama, etik dan moral akan mendukung hasil-hasil pengembangan ilmu hukum, dengan demikan untuk mengkaji dan memahami hukum harus lebih menekankan hal yang sifatnya substantif dan transendental dengan mendasarkan pada fakta sosial yang tidak lepas dari nilai-nilai agama, etik dan moral. ${ }^{14}$

Fenomena ini memperlihatkan, pemikiran hukum di Indonesia ini pada hakikatnya mengalami involutif. Pemikiran-pemikiran hukum tampak statis dan sepi dari perdebatan.

14 Absori, 2005, Hukum Dan Dimensi Spiritual: Perspektif Positivis, Pospositivis dan Spiritualisme, PROFETIKA, Jurnal Studi Islam Vol. 7 No. 2 Tahun 2005, diterbitakan oleh Magister Pemikiran Islam 
Sementara itu, beberapa ahli ilmu sosial berpendapat, bahwa ilmu hukum di Indonesia tidak mengalami kemajuan dengan kata lain terjadi suatu kemandegan. ${ }^{15}$ Dalam involusinya pemikiran hukum tersebut Satjipto Rahardjo memperkenalkan paradigma hukum progresif.

Kehadiran hukum progresif $^{16}$ bukanlah sesuatu yang kebetulan, bukan sesuatu yang lahir tanpa sebab, dan juga bukan sesuatu yang jatuh dari langit. Hukum progresif adalah bagian dari proses pencarian kebenaran (searching for the truth) yang tidak pernah berhenti. Hukum progresif yang dapat dipandang sebagai konsep yang

\footnotetext{
Program Pascasarjana Univesitas Muhammadiyah Surakarta.

${ }^{16}$ Satjipto Rahardjo memberikan beberapa label untuk pemikiran hukum progresif dianataranya: pertama, gerakan intelektual (seperti critical legal studies movement (CLS) di Amerika Serikat. Lihat, Satjipto Rahardjo, Hukum Progresif: Sebuah Sintesa Hukum Indonesia, Yogyakarta, Genta Publishing, 2009, hlm. 22 dan 52. Kedua, suatu paradigma (Paradigma yang disodorkan di sini adalah 'hukum untuk manusia' sebagaimana disebut di atas. Lihat, Satjipto Rahardjo, Negara Hukum yang Membahagiakan Rakyatnya, Yogyakarta, Genta Publishing, 2009, hlm. 70) dan; Ketiga, konsep mengenai cara berhukum (ia juga menulis, "Hukum progresif adalah sebuah konsep mengenai cara berhukum. Cara berhukum tidak hanya satu; melainkan bermacam-macam. Di antara cara berhukum yang bermacam-macam itu, hukum progresif memiliki tempatnya sendiri." Baca Satijpto Rahardjo, "Hukum Progresif: Aksi, BukanTeks," dalam Satya Arinanto \& Ninuk Triyanto, ed., Memahami Hukum: dari Konstruksi sampai Implementasi (Jakarta: Rajawali Pers, 2009), hlm. 3.
}

sedang mencari jati diri, bertolak dari realitas empirik tentang bekerjanya hukum dimasyarakat, berupa ketidakpuasan dan keprihatinan terhadap kinerja dan kualitas penegakan hukum dalam setting Indonesia akhir abad ke-20.

$$
\text { Gagasan hukum progresif }
$$
muncul sebagai reaksi keprihatinan terhadap keadaan hukum di Indonesia yang sedemikian rupa sehingga muncul pendapat dari pengamat internasional hingga masyarakat awam bahwa sistem hukum Indonesia masih jauh dari harapan dan memerlukan pembenahan secara serius. Gagasan Hukum Progresif muncul sebagai reaksi atas "kegagalan" hukum Indonesia yang didominasi doktrin positivism dalam menanggulangi kasus-kasus korupsi dan pelanggaran hak asasi manusia. Hal tersebut bisa dilihat setidaknya gejalanya Pada tahun 1970-an ada istilah "mafia peradilan" dalam kosakata hukum di Indonesia, pada orde baru hukum sudah bergeser dari social engineering ke dark engineering karena digunakan untuk mempertahankan kekuasaan. Pada era reformasi dunia hukum makin mengalami komersialisasi. Menurut Satjipto Rahardjo, inti dari kemunduran di atas adalah makin 
langkanya kejujuran, empati dan tujuan-tujuandi luar narasi tekstual dedikasi dalam menjalankan hukum. ${ }^{17}$ hukum itu sendiri; Legal Realism;

Penegakan hukum progresif Freirerechtslehre; Critical Legal adalah menjalankan hukum tidak hanya Studies. ${ }^{19}$ Sekalipun hukum progresif sekedar kata-kata hitam-putih dari bersama aliran-aliran hukum tersebut peraturan (according to the letter), mengkritik doktrin hukum positif, melainkan menurut semangat dan namun hukum progresif sebenarnya makna lebih dalam (to very meaning) tidak antai terhadap keberadaan sistem dari undang-undang atau hukum. hukum positif.

Penegakan hukum tidak hanya Konsep "progresivisme" kecerdasan intelektual, melainkan bertolak dari pandangan kemanusiaan dengan kecerdasan spiritual. Dengan kata lain, penegakan hukum yang dilakukan dengan penuh determinasi, empati, dedikasi, komitmen terhadap penderitaan bangsa dan disertai sehingga berupaya merubah hukum yang tak bernurani menjadi institusi yang bermoral. Paradigma "hukum untuk manusia" membuatnya merasa keberanian untuk mencari jalan lain daripada yang biasa dilakukan. ${ }^{18}$

bebas untuk mencari dan menemukan format, pikiran, asas serta aksi-aksi Dari sudut teori, maka hukum yang tepat untuk mewujudkan tujuan hukum yakni keadilan, kesejahteran progresif meninggalkan tradisi dan kepedulian terhadap rakyat. analitical jurisprudence atau Dengan kata lain hukum progresif rechtsdogmatiek dan mengarah pada bersifat membebaskan manusia dari tradisi sociological jurisprudence. Jadi kelaziman baik yang bersumber dari sebenarnya konsep hukum progresif peraturan perundang-undangan bersentuhan, dipengaruhi atau berbagai maupun prosedur serta kebiasaan dengan beberapa teori hukum yang praktik hukum. Dalam sistem hukum telah mendahuluinya, antara lain: yang progresif, ahli hukum tidak hanya Konsep hukum responsif (responsive berperan sebagai penegak hukum law) yang selalu dikaitkan dengan dalam arti sempit (menemukan hukum

${ }^{17}$ Faisal, Menerobos Positivisme Hukum, Rangkang Education, Yogyakarta, 2010, hlm. 70

${ }^{18}$ Satjipto Rahardjo, Penegakan Hukum Suatu Tinjauan Sosiologis, Genta Publishing,

Yogyakarta, 2009, hlm. xiii dalam aturan formal dan

\footnotetext{
${ }^{19}$.Shidarta, "Posisi Pemikiran Hukum Progresif Dalam Konfigurasi Aliran-aliran Filsafat Hukum: Sebuah Diagnosis Awal”,. Halaman 52.
} 
menerapkannya) namun lebih dari itu harus mampu sebagai "kreator hukum".

Menjalankan hukum secara progresif tidak semata-mata berpijak pada rule and logic namun juga rule and behavior. Hal ini mengingatkan pada penyataan Oliver Wendell Holmes: "...The live of the law has not been logic. It has been experience". Menggunakan hukum tidak sematamata mengandalkan logika peraturan namun juga harus mempertimbangkan hukum yang bersumber dari pengalaman empiris misalnya kearifan lokal. Karena bertumpu pada dua pijakan yakni peraturan dan perilaku maka hukum progresif tidak memposisikan hukum sebagai intuisi yang netral. Hukum Progresif merupakan hukum yang berpihak yakni memberi perhatian pada yang lemah, prorakyat dan pro keadilan. $^{20}$

Hukum yang diposisikan sebagai intuisi yang netral merupakan pengaruh dari paham liberalisme yang apabila diterapkan pada situasi yang timpang justru cenderung

\footnotetext{
${ }^{20}$.Sudijono mengidentifikasikan elemenelemen utama dari model hukum progresif, yakni: Ideologi: "pro-rakyat"; Tujuan: "pembebasan"; Fungsi: "Pemberdayaan"; Jenis keadilan: "keadilan sosial" dan Metodologi: “diskresi”. Periksa: Sudijono Sastroadmodjo, "Konfigurasi Hukium
}

menguntungkan pihak yang kuat. Sebagaimana telah dikemukakan bahwa dalam mewujudkan tujuannya hukum bukanlah merupakan sesuatu yang mutlak dan final tetapi selalu "dalam proses menjadi" (law as process, law in the making) yakni menuju kualitas kesempurnaan dalam arti menjadi hukum yang berkeadilan, hukum yang mampu mewujudkan kesejahteran atau hukum yang peduli terhadap rakyat. Bahkan hukum progresif menginisiasi konsep "rule breaking" yakni merobohkan hukum yang dipandang tidak mampu mewujudkan keadilan dan membangun kembali hukum yang lebih baik.

Menjalankan hukum progresif berarti meninggalkan cara berhukum dengan "kacamata kuda" (masinal, atomizing, mekanistik, linier) dan merubahnya menjadi pada cara pandang yang utuh (holistic) dalam membaca aturan dan merekonstruksi fakta. Dengan demikian Dalam menghadapi situasi yang bersifat extraordinary pekerja hukum harus menjalankan profesi atau tugas melampaui batas beban tugasnya (Mesubudi/doing to the utmost). ${ }^{21}$

Progresif". Jurnal Ilmu Hukum, Volume 8 Nomor 2, September 2005. Halaman 187.

${ }^{21}$ Wisnubroto, 2014, Dasar-Dasar Hukum Progresif, Materi Sekolah Hukum Progresif 
Menurut Satjipto Rahardjo, kasus hukum, khususnya di dalam semenjak hukum modern digunakan, negeri yang menekankan preposisi pengadilan bukan lagi tempat untuk teori Hukum Progresif. Terutama mencari keadilan (searching of justice), penekanan pada unsur kemanfaatan melainkan menjadi lembaga yang berupa ketentraman manusia dalam berkutat pada aturan main dan masyarakat, berbangsa dan bernegara. prosedur. Hukum kemudian dipahami Pemikiran hukum perlu semata-mata sebagai produk dari kembali pada filosofi dasarnya, yaitu negara dalam bentuk peraturan hukum untuk manusia. Dengan filosofi perundang-undangan. $^{22}$ Oleh karena tersebut, maka manusia menjadi itu, maka bagi Satjipto Rahardjo, penentu dan titik orientasi hukum. hukum bukanlah suatu skema yang final (finite scheme), namun terus bergerak, berubah, mengikuti dinamika kehidupan manusia. Hukum harus terus dibedah dan digali melalui upayaupaya progresif untuk menggapai terang cahaya kebenaran dalam menggapai keadilan. ${ }^{23}$

Hukum sebagai kaidah dan pedoman yang mengatur kehidupan dalam bermasyarakat agar tercipta ketentraman dan ketertiban bersama. Gagasan Hukum Progresif menempati posisi hukum tersendiri. Berbagai kalangan dalam penanganan suatu

Angkatan I, Kerjasama Laboratorium Hukum FH UAJY dengan PSHP (Paguyuban Sinau Hukum Progresif), KMMH (Keluarga Mahasiswa Magister Hukum) UGM dan IMM (Ikatan Mahasiswa Muhammadiyah) UMY, Yogyakarta, 18-19 November 2014. hlm. 1-14

${ }^{22}$ Satjipto Rahardjo, 2009, Penegakan Hukum: Suatu Tinjauan Sosiologis, Genta Publishing, Yogyakarta, hlm.ix.

${ }^{23}$ Satjipto Rahardjo, 2010, Penegakan Hukum Progresif, Kompas, Jakarta, hlm.vii.

Hukum bertugas melayani manusia, bukan sebaliknya. Oleh karena itu, hukum itu bukan merupakan institusi yang lepas dari kepentingan manusia.

Kualitas hukum ditentukan oleh kemampuannya untuk mengabdi kepada kesejahteraan manusia. Ini menyebabkan Hukum Progresif menganut ideologi "hukum yang prokeadilan dan hukum yang prorakyat". Dengan ideologi ini, dedikasi para pelaku hukum mendapat tempat yang utama untuk melakukan pemulihan. Para pelaku hukum dituntut mengedepankan kejujuran dan ketulusan dalam penegakan hukum. Mereka harus memiliki empat dan kepedulian pada penderitaan yang dialami rakyat dan bangsa ini. Kepentingan rakyat (kesejahteraan dan kebahagiaannya) harus menjadi titik 
orientasi dan tujuan akhir alur linier, marsinal, dan deterministic, penyelenggaraan hukum.

serta lebih ke arah hukum yang Asumsi yang mendasari senantiasa berproses (law as process, progresivisme hukum adalah: ${ }^{24}$ law in the making. ${ }^{25}$

a. Hukum adalah untuk manusia, dan Orientasi paradigma profetik tidak untuk dirinya sendiri.

dalam penegakan hukumnya

b. Hukum itu selalu berada pada sebenarnya "mirip" dengan gagasan status law in the making dan tidak bersifat final.

hukum progresif yang dideklarasikan oleh Satjipto Rahardjo, dimana

c. Hukum adalah institusi yang manusia dan rakyat merupakan tujuan bermoral kemanusiaan, dan bukan teknologi yang tidak bernurani. dari keberadaan hukum. Penegakan hukum hukum progresif sebagaimana Asumsi yang mendasari Suparman Marzuki katakan, ialah progresivisme hukum tersebut penegakan hukum yang submisif menekankan bahwa Hukum Progresif terhadap sistem yang ada, tetapi lebih adalah hukum yang membebaskan. afirmatif (affirmatif law enforcement). "Hukum untuk manusia" artinya, Afirmatif berarti keberanian untuk apabila terjadi hambatan-hambatan melakukan pembebasan dari praktek terhadap pencapaiannya maka konvensional dan menegaskan dilakukan pembebasan-pembebasan, penggunaaan satu cara yang lain, yang baik dalam berilmu, berteori, dan menerobos terhadap pakem-pakem berpraktik. Perspektif Hukum Progresif praktek hukum yang telah lama tidak bersifat pragmatis dan kaku, yang berlangsung. Aparatur penegak hukum menggarap hukum semata-mata HAM bersikap realistis, tidak menggunakan "rule and logic" atau bermukim di menara gading. Mereka rechtdogmatigheid, dengan alur harus mengasah intuisi dengan dengan berfikir linier, marginal, dan turun ke bawah menyerap aspirasi yang deterministik. Bahwa paradigma berkembang di masyarakat. Para Hukum Progresif akan senantiasa penegak hukum harus menjadi agen mencari keadilan dan kemanfaatan perubahan dan tidak menjadi staf hukum dan harus berani keluar dari sistem hukum. Mereka harus berani

24 Arief Barda Nawawi, 1984, Kebijakan Hukum Pidana (Penal Policy), Universitas Diponegoro, Semarang, hlm.112.

25 Satjipto Rahardjo, Penegakan Hukum Progresif, Op.cit, hlm. 46. 
mendobrak sekat-sekat yang dibangun oleh ideologi-ideologi penindas keadilan sosial. Mereka harus keluar dari tafsir monolitik karena teks undang-undang hanya memberi ruang penafsiran yang terbatas. Penegakan hukum progresif lebih mengedepankan konteks ketimbang teks-teks aturan semata. $^{26}$

Paradigma profetik memliki basis transedensi, orientasi humanisasi dan liberasi yang tertanam dalam diri penegak hukum akan mendorong eksistensinya untuk selalu total dalam melakukan penemuan-penemuan hukum (ijtihad al hukmi) yang obyektif untuk diterapkan pada suatu kasus. Penegak hukum dalam konteks ini ditempatkan dalam posisi yang sangat strategis dan menentukan, yaitu seorang mujtahid. Posisinya harus berfikir keras untuk menjadi bagian dari penegak hukum yang mampu mencatatkan sejarah kemanusiaan dan terlibat dalam membangun tatanan yang beradab. Keputusannya harus melandaskan terhadap dasar-dasar ilmu yang kritis dan intuitif, prilaku harus terjaga secara etik dan profetik dan

26 Suparman Marzuki, Robohnya Keadilan : Politik Hukum HAM Era Reformasi, Pusham UII, Yogyakarta, 2011, hlm 269270 berlomba-lomba untuk menjadi suri teladan dalam penegakan hukum.

Cita-cita penegakan hukum paradigma profetik sama dengan citacita penegakan hukum progresif. Cuma dalam hukum progresif sebagaimana Satjipto deklarasikan tidak menyinggung posisi transedensi sebagai dasar penegakan. Sehingga dasar orientasi penegakannya semata humanisme sebagaimana yang berkembang dalam masyarakat pembebasan eropa. Sedangkan paradigma profetik, orientasi humanisasi dan liberasi dalam hukum harus berpijak pada transedensi, sehingga penegakan hukum tidak semata bertanggungjawab secara materi, tetapi juga bertanggungjawab secara immateri.

Keberaadan transedensi dalam penegakan hukum berparadigma profetik merupakan satu yang fundamental. Ketiadaannya, akan menyelamkan orientasi humanisasi dan liberasi ke dalam humanisme eropa yang memang menjauhkan ilmu dari agama dengan landasan harus bebas nilai. ${ }^{27}$ Penganut hukum berparadigma positivisme kukuh dalam hal ini,

\footnotetext{
27 Husnul Muttaqin, Menuju Sosiologi Profetik, dalam Jurnal Sosiologi Reflektif, Vo. 1 Edisi 1, Oktober 2006, Prodi
} 
bahwa secara metodologis ilmu pasti terbagi menjadi "bebas nilai" dan "tidak bebas nilai". Dalam perspektif paradigma profetik semua ilmu "tidak akan bebas nilai", karena ilmu terintegrasi dengan agama yang meneguhkan moralitas dan etika. Bahkan, kelahiran paradigma profetik salah satunya dilandasi atas kegelisahan Kuntowijoyo dari eksistensi renaisance dan humanisme yang kemudian membentuk modernitas yang pada kenyataannya berelasi dengan peran-peran borjuasi dalam masyarakat eropa. $^{28}$ Transedensi menjadi sangat vital untuk mendasari kekuhan moral dan memperkuat nilainilai etis pada setiap manusia.

Demikian juga berlaku bagi aturan hukum dan para penegak. Keduanya tidak mungkin bebas nilai, sehingga keberadaan keduanya harus dioptimalisasi dan didekonstruksi terus menerus sehingga memunculkan makna-makna etik dan progresif bagi tegaknya keadilan, kemanusiaan dan peradaban. Untuk mewujudkan humanisasi dan liberasi berbasis transendensi maka "objektifikasi" menjadi salah satu alat tranformatifnya.

Sosiologi Fakultas Ilmu Sosial dan Humaniora UIN Yogyakarta, hlm 2
Objektifikasi ialah perbuatan rasional nilai (wertrational) yang diwujudkan ke dalam perbuatan rasional, sehingga orang luar pun dapat menikmati tanpa harus menyetujui nilai-nilai asal. Contohnya, ancaman Tuhan kepada orang Islam sebagai orang yang mendustakan agama bila tidak memperhatikan kehidupan ekonomi orang-orang miskin, maka dapat diobjektifikasi dengan program IDT. Kesetiakawanan nasional adalah objektifikasi dari ajaran tentang ukhuwah. ${ }^{29}$ Maka secara metodologis, paradigma profetik jika dilpersonalisasi terhadap penegak hukum, pola yang akan terbangun ialah :

Pertama, para penegak hukum harus mentranformasi "hukum yang abstrak pada yang kongkrit. Hukum di Indonesia selama ini dengan paradigma positivismenya berada di menara gading, dan tidak menyentuh terhadap fakta-fakta riil yang sifatnya sosiologis masyarakat. Hukum menjadi bahasa yang kaku, melangit dan tidak membumi dengan kondisi sosiologis ketika ditegakkan. Maka hukum mesti dibumikan dan dikongkritisasi sehingga menjadi berkah bagi

\footnotetext{
28 Kuntowijoyo, Peran Borjuasi Dalam Tranformasi Eropa, Ombak, Yogyakarta, 2005, hlm 16-28

${ }^{29}$ Ibid, hlm 17-20
} 
kehidupan sosial serta mampu menjadi tawaran solusi yang efektif bagi persoalan-persoalan yang riil yang dihadapi oleh masyarakat. ${ }^{30}$

Kedua, para penegak hukum harus mentranformasi "hukum ideologis menjadi ilmu". Ideolog menurut Kuntowijoyo bersifat subyektif, normati dan tertutup. Berbeda dengan ilmu yang bersifat terbuka, obyektif, dan faktual. Hukum yang diletakkan dalam konteks ideologis seringkali mengalami kesulitan-kesulitan ketika mau ditegakkan dalam kehidupan masyarakat. Maka penegak hukum mampu untuk mengilmukan hukum sehingga sesuai dengan kebutuhankebutuhan masyarakat yang multikulturalistik. Hukum yang berada dalam posisi ideologis cenderung akan sentralistik, dominatif

dan memarjinalisasi. Paradigma ideologi harus diubah menjadi ilmu, karena dalam ideologi kenyataan ditafsirkan tergantung kaidah-kaidah yang diyakini kebenaranya. Sedangkan dalam perspektif ilmu, kenyataan akan dilihat sebagai kenyataan yang otonom dari kesadaran pemandangnya. Pendekatan ilmu dalam konteks hukum

${ }^{30}$ Ibid, hlm 20-23 nanti akan melahirkan konsep-konsep yang obyektif, teoritis, faktual dan terbuka.

Ketiga, penegak hukum harus mentranformasikan dirinya yang subyektif pada persoalan yang obyektif. Positioning tranformatif subyektif menuju obyektif merupakan cita-cita penegakan hukum yang selama ini tersentrum pada watak subyektif penegak hukum, padahal penegak hukum tersebut belum melakukan obyektifikasi terhadap kasus-kasus yang ditanganinya. Sehingga yang terjadi adalah putusan yang tidak adil, sewenang-wenang dan tidak sesuai dengan realitas yang terjadi sebenarnya. Obyektifikasi menghendaki pemaknaan-pemaknaan yang realistik. Kuntowijoyo mencontoh- kan, zakat secara subyektif bertujuan untuk membersihkan harta dan jiwa, tetapi sesungguhnya sisi obyektifnya tujuan zakat intinya ialah tercapainya kesejahteraan sosial. Pemaknaan bahwa Islam menghendaki kesejahteraan sosial harus selalu dikembangkan. ${ }^{31}$

Pemikiran Kuntowijoyo di atas memberikan solusi terhadap eksistensi

31 Kuntowijoyo, Paradigma Islam... Op. Cit, hlm 284, lihat juga Kuntowijoyo, Identitas Politik.. Op. Cit, hlm 23-26 
hukum yang telah stagnan, koruptif, anti sosial masyarakat, dan terjadi sakralisasi pasal-pasal sehingga tidak obyektif ketika diberlakukan. Kerangka pemikiran Kuntowijoyo sangat signifikan menawarkan kerangkan teorisasi dalam hukum, strukturalisme transendental dalam perjuangan menegakkan humanisasi dan liberasi hukum, serta praksis metodologis yang sifatnya transformatif konstruktif. Keberadaan paradigma profetik dengan basis kerangka di atas, sangat terasa signifikansinya untuk menjadi alat membaca ulang terhadap penegakan hukum di Indonesia yang hari ini masih berjibun dengan problem modernitasnya yang sekularistik dan parsial.

\section{Pendekatan Paradigma Profetik: Sebuah Tawaran}

Seorang Belanda, bernama Taverne, terkenal dengan kata-katanya yang berbunyi, "berikan kepada saya hakim dan jaksa yang baik, maka dengan peraturan yang buruk pun saya bisa membuat putusan yang baik". Kata-kata Taverne itu mencerminkan bahwa baiknya suatu putusan hakim tidak tergantung kepada baiknya peraturan yang dibuat. Ia ingin menyatakan bahwa peraturan perundang-undangan yang baik dan sempurna sekali pun, jika penerapannya oleh orang yang berperilaku buruk, maka hasilnya akan buruk dan mengecewakan banyak pihak.

Hakim dapat digolongkan kepada dua golongan, yaitu hakim yang hanya berpegang kepada teks formal saja dan hakim yang teks hanya dijadikan panduan, maka hakim golongan kedua dianggap sebagai hakim yang berpardigma profetik. Selanjutnya dalam proses memutus suatu perkara, hakim dapat dibagi kepada dua tipe, yaitu: pertama, adalah hakim yang apabila memeriksa ia bertanya kepada putusan hatinya terlebih dahulu dan kemudian baru mencarikan pasal-pasal undangundangnya untuk legitimasi, kedua, hakim yang apabila memeriksa, bertanya kepada "perutnya" terlebih dahulu dan kemudian baru mencarikan pasal-pasal untuk memberi legitimasi.

Hakim tipe pertama telah berpikir secara sempurna karena menggunakan hati nuraninya atau kecerdasan spiritual. Logika yang dibangun tidak hanya menggunakan "logika peraturan" tetapi telah menggunakan "logika kepatutan 
sosial" (social reasonableness) dan "logika keadilan". 32

Pembinaan aparat penegak hukum melalui kecerdasan spiritual yang akan melahirkan paradigma profetik bisa dimulai dengan pendekatan yang ditawarkan oleh Danah Zohar dan Ian Marshall. Pendekatan yang mereka gunakan adalah dengan mengenalkan berpikir spiritual (spiritual tinking). Melalui kecerdasan spiritual (spiritual quition), akan diperoleh kecerdasan yang paling sempurna (ultime intelegent) sehingga dapat menerabas garis-garis formalisme (existing rule) menuju trasedental yang mendekati kebenaran yang hakiki (the ultimate truth).

Spritual quition merupakan alat bagi manusia untuk dapat membangun berbagai perspektif baru dalam kehidupan baru dalam kehidupan, dunia yang sempit dan bisa merasakan kehadiran tuhan tanpa bertemu dengan Tuhan. Untuk pembinaan para hakim dengan pendekatan kecerdasan spiritual perlu diarahkan pada pembinaan moral, kejujuran, integritas, kepribadian layak dipercaya, dan mempunyai kebanggaan menjadi

${ }^{32}$ M. Amin, Hukum dan Hakim Progresif, Opini, harian Waspada Medan tanggal 6 Juli 2011 hakim sebagai sebagai jabatan yang mulia.

Disamping itu, tidak kalah pentingnya perlu dilakukan pembinaan spiritual berdasarkan ajaran agama yang diyakininya, yang menyadarkan bahwa tugas aparat penegak hukum (hakim) sarat dengan tugas keadilan yang membahasakan dengan nama Allah untuk memutus perkara dengan berdasarkan keadilan. Pembinaan aparat penegak hukum (hakim) dengan pendekatan SQ, di dalamnya terdapat penyadaran dan pesan spiritual bahwa seorang hakim adalah wakil (wali) Allah di muka bumi (fil ardhi), ia menjaankan tugas atas nama Allah dalam menjalankan keputusan di pengadilan dengan hati nurani dan nilai-nilai keadilan.

Dengan demikian, apa yang dilakukan aparat penegak hukum (hakim) semata dalam rangka menjalankan amanat mulia, sekaligus di dalamnya terkandung amanat pengabdian (ibadah) kepada Tuhannya. Pembinaan hakim dengan pendekatan SQ sesuai dengan amanat tugas seorang hakim yang menjatuhkan keputusan berdasarkan "Demi Keadilan Berdasarkan Ketuhanan Yang Maha Esa". Tugas yang dijalankan seorang hakim adalah tugas spiritual 
dengan mengatasnamakan Tuhan dan Keadilan. $^{33}$

Dari uraian di atas, penulis meyakini, bahwa hanya hakim yang menggunakan paradigma profetik dalam penegakan hukum kebakaran hutan melalui kecerdasan spiritual yang bisa membebaskan negeri ini dari perusak, pembakar dan penyelahgunaan hutan. Dan hakim berparadigma profetik itu pula yang akan dapat membawa lembaga peradilan (Mahkamah Agung RI) menjadi peradilan yang Agung dengan lahirnya putusan-putusan yang memberi perlindungan dan kesejahteraan masyarakat.

\section{KESIMPULAN}

Kualitas hukum ditentukan oleh kemampuannya untuk mengabdi kepada kesejahteraan manusia. Ini menyebabkan Hukum Progresif menganut ideologi "hukum yang prokeadilan dan hukum yang prorakyat". Dengan ideologi ini, dedikasi para pelaku hukum mendapat tempat yang utama untuk melakukan pemulihan. Para pelaku hukum dituntut mengedepankan kejujuran dan

\footnotetext{
${ }^{33}$ Absori, Hegemoni Mainstream Positivistik: Dinamika dan Orientasi Pemahaman dan Penegakan Hukum, presentasi makalah, tidak dipublikasikan.
}

ketulusan dalam penegakan hukum. Mereka harus memiliki empati dan kepedulian pada penderitaan yang dialami rakyat dan bangsa ini. Kepentingan rakyat (kesejahteraan dan kebahagiaannya) harus menjadi titik orientasi dan tujuan akhir penyelenggaraan hukum.

Sementara itu, Paradigma profetik dalam penegakan hukum dimulai dengan pembinaan penegak hukum melalui kecerdasan spiritual yang ditawarkan oleh Danah Zohar dan Ian Marshall. Pendekatan yang mereka gunakan adalah dengan mengenalkan berpikir spiritual (spiritual tinking). Melalui kecerdasan spiritual (spiritual quition), akan diperoleh kecerdasan yang paling sempurna (ultime intelegent) sehingga dapat menerabas garis-garis formalisme (existing rule) menuju trasedental yang mendekati kebenaran yang hakiki (the ultimate truth). Pembinaan hakim dengan pendekatan SQ sesuai dengan amanat tugas seorang hakim yang menjatuhkan keputusan berdasarkan "Demi Keadilan Berdasarkan Ketuhanan Yang Maha Esa". Tugas yang dijalankan seorang hakim adalah tugas spiritual dengan mengatasnamakan Tuhan dan Keadilan. 


\section{REFERENSI}

Absori, 2001, Penegakan Hukum Lingkungan dan Antisispasi Dalam Era Perdagangan Bebas, Muhammadiyah University Press, Surakarta.

2005, Penegakan Hukum Lingkungan Di Era Reformasi, 4 Jurnal Ilmu Hukum, Vol 8 No.2

, 2004, Peran Serta Masyarakat Dalam Penegakan AMDAL, Jurnal Yurisprudence, Vol.1,No.2

2016, Penegakan Hukum Terhadap

Korporasi di Bidang Lingkungan Hidup. Slide Pemakalah, tidak dipublikasikan

, 2015, Epistimologi Ilmu

Hukum Transendental dan Implementasinya dalam Pengembangan Program Doktor Ilmu Hukum, Disampaikan pada Seminar Nasional dengan Tema "Pengembangan Epistimologi Ilmu Hukum", 11 April 2015 di Universitas Muhammadiyah Surakarta.

, 2005, Hukum Dan Dimensi Spiritual: Perspektif Positivis, Pospositivis dan Spiritualisme, PROFETIKA, Jurnal Studi Islam Vol. 7 No. 2 Tahun 2005, diterbitakan oleh Magister Pemikiran Islam Program Pascasarjana Univesitas Muhammadiyah Surakarta.

2016, Hegemoni Mainstream Positivistik: Dinamika dan Orientasi Pemahaman dan Penegakan Hukum, presentasi makalah, tidak dipublikasikan.
Abdul Hakim G. Nusantara, 1988, Politik Hukum Indonesia, Yayasan Lembaga Bantuan Hukum Indonesia, Jakarta

Elviandri, Tanda Ketidak Berdayaan Pemerintah, Artikel Harian Vokal - Riau, 14 September 2015

M Unger, Roberto, 1999, The Critical Legal Studies Movement (1983), diterjemahkan Ifdhal Kasim, Jakarta: Elsam

Hamid, Hamrat dan Pramudyanto, Bambang. 2007. Pengawasan Industri Dalam Pengendalian Pencemaran Lingkungan, Edisi I. Jakarta : Granit.

Surbakti, Natangsa, 2012, Dialektika Hukum Modern Dan Hukum Tradisional Dalam Bingkai Logika Revolusi Sains, Jurnal Ilmu Hukum, Vol. 15, No. 2, September.

Faisal, 2010, Menerobos Positivisme Hukum, Rangkang Education, Yogyakarta

Rahardjo, Satjipto, 2009, Penegakan Hukum Suatu Tinjauan Sosiologis, Genta Publishing, Yogyakarta , 2010, Penegakan Hukum Progresif, Kompas, Jakarta

2009, Hukum Progresif: Sebuah Sintesa Hukum Indonesia, Yogyakarta, Genta Publishing, 
2009, Negara Hukum yang Membahagiakan Rakyatnya, Yogyakarta, Genta Publishing,

2009 "Hukum

Progresif: Aksi, BukanTeks," dalam Satya Arinanto \& Ninuk Triyanto, ed., Memahami Hukum: dari Konstruksi sampai Implementasi, Jakarta, Rajawali Pers,

Shidarta, "Posisi Pemikiran Hukum Progresif Dalam Konfigurasi Aliran-aliran Filsafat Hukum: Sebuah Diagnosis Awal".

Sastroadmodjo, Sudijono, 2005 "Konfigurasi Hukium Progresif". Jurnal Ilmu Hukum, Volume 8 Nomor 2, September.

Wisnubroto, 2014, Dasar-Dasar Hukum Progresif, Materi Sekolah Hukum Progresif Angkatan I, Kerjasama Laboratorium Hukum FH UAJY dengan PSHP (Paguyuban Sinau Hukum Progresif), KMMH (Keluarga Mahasiswa Magister Hukum) UGM dan IMM (Ikatan Mahasiswa Muhammadiyah) UMY, Yogyakarta, 18-19 November 2014.

Barda Nawawi, Arief, 1984, Kebijakan Hukum Pidana (Penal Policy), Universitas Diponegoro, Semarang

M. Amin, Hukum dan Hakim Progresif , Opini, harian Waspada Medan tanggal 6 Juli 2011
Suparman Marzuki, 2011, Robohnya Keadilan : Politik Hukum HAM Era Reformasi, Pusham UII, Yogyakarta

Tempo, Hukum Pembakaran Hutan, 31 Januari 2016.

Husnul Muttaqin, Menuju Sosiologi Profetik, dalam Jurnal Sosiologi Reflektif, Vo. 1 Edisi 1, Oktober 2006, Prodi Sosiologi Fakultas Ilmu Sosial dan Humaniora UIN Yogyakarta

Kuntowijoyo, Peran Borjuasi Dalam Tranformasi Eropa, Ombak, Yogyakarta,

Yudi Kristiana, 2007, Rekonstruksi Birokrasi Kejaksaan dengan Pendekatan Hukum Progresif dengan subjudul Studi tentang Penyelidikan, Penyidikan, dan Penuntutan Tindak Pidana, Disertasi Program Doktor Ilmu Hukum Program Pascasarjana Universitas Diponegoro Semarang, tidak dipublikasikan. 


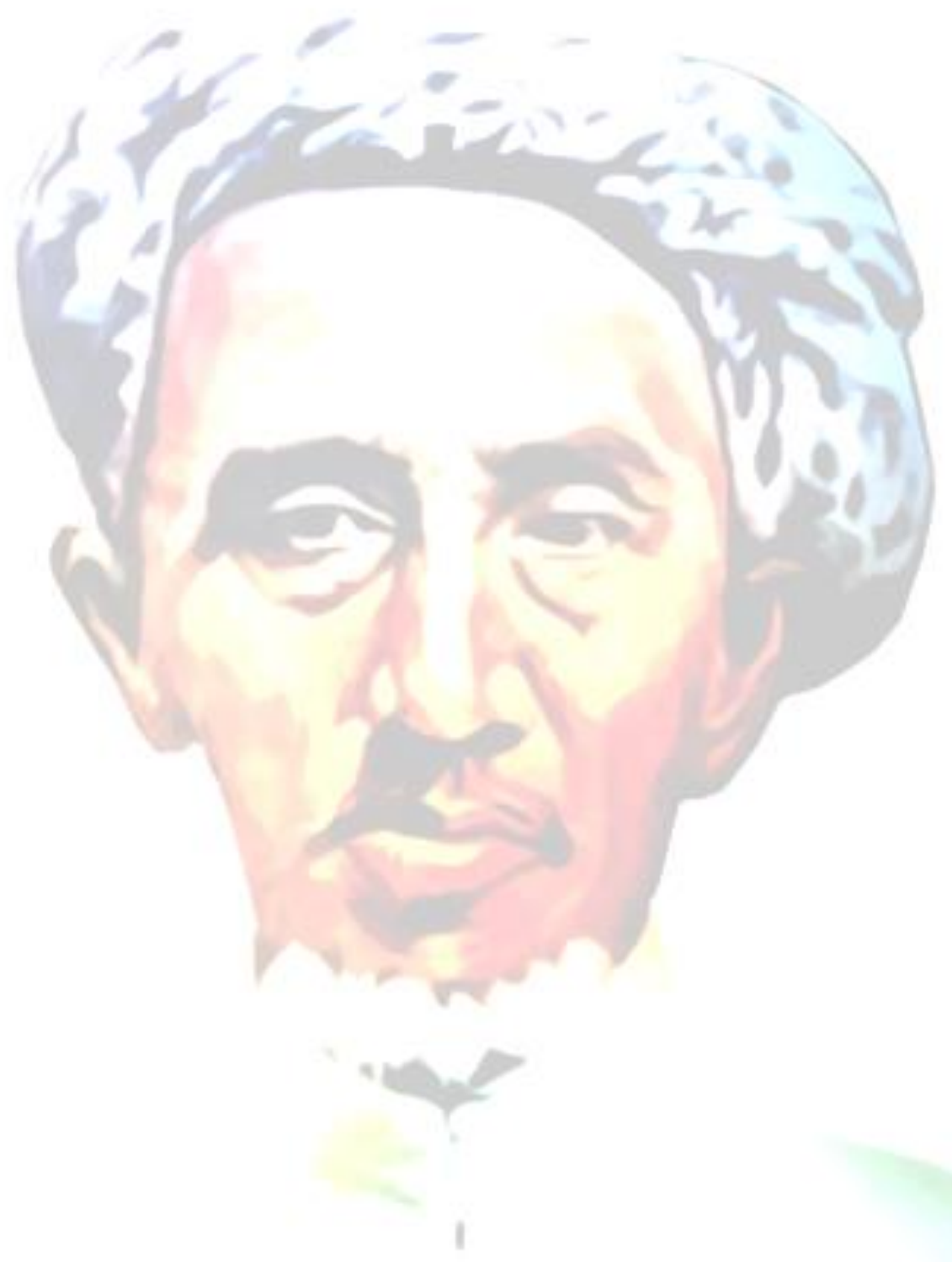

